\title{
Oxford
}

\section{The Elements of Life}

Biography and Portrait-Painting in Stuart and Georgian England

RICHARD WENDORF, Harvard University

In this bold new study, Wendorf compares two arts--biography and portraitpainting, and reveals that despite their obvious differences, visual and verbal portraits often shared similar assumptions about the representation of historical character. 1990275 pp.; 40 b\&w halftones $\$ 59.00$

\section{Church and State in Early Modern England, 1509-1640}

\section{LEO F. SOLT, Indima University, Bloomington}

"I know of no modern work that covers the same ground.... It reflects the author's subtle mind, understanding of the period, and careful judgment. His use of printed sources, weaving them in to his narrative in order to capture the precise flavor and meaning of authors and ideas, is masterful."

- Martin J. Havran, University of Virginia $1990 \quad 288 \mathrm{pp} . \$ 35.00$

\section{Gentlemen and Barristers}

The Inns of Court and the English Bar 1680-1730

DAVID LEMMINGS, University of Adelaide

In this original study, Lemmings shows how the four inns of court declined from their former splendor during the late seventeenth century until, by the reign of George II, they were principally dormitories and offices for a mass of nonlawyers. (()xford Historical Monographs) $1990 \quad 344$ pp.; illus. $\$ 55.00$

\section{The Thatcher Effect}

\section{A Decade of Change}

Edited by DENNIS KAVANAGH, Unizersity of Nottinghtam, and ANTHONY SELDON

This collection of essays examines the principal changes that have occurred in Britain since 1979, the role of the Thatcher government in promoting these changes, and the extent to which change would have occurred regardless of the government in power. 1989376 pp.; illus. paper $\$ 12.95$

\section{New in paperlack!}

\section{Tudor England}

JOHN GUY, Lnizersity of Bristol

"The first comprehensive history of Tudor England for thirty years." - Observer "Guy handles the traditional themes of power and religion with authority and conviction... Iucid, scholarly, remarkably accomplished, provides an excellent overview." - Sunday Times (London)

1988 (paper 1990) 624 pp.; illus. paper $\$ 14.95$

\section{The Gladstone Diaries}

With Cabinet Minutes and Prime-Ministerial Correspondence

Volumes $X$ and XI

WILLIAM EWART GLADSTONE; edited by H.C.G. MATTHEW, St. Hugh's College, Oxford and Christ Church, Oxford

Pralise for the Gladstome Diarie's: "Fundamental to the study of Gladstone's

character and career.... An indispensable resource for specialists." - Albion "[A] monumental publishing venture." - Victorian Studies. The tenth and eleventh volumes of Gladstone's diaries cover 1881 to 1886 , the years of Gladstone's highly dramatic second and third administrations.

Volume X: March $1990712 \mathrm{pp}$; f frontis., $4 \mathrm{pp}$. plates $\$ 98.00$

Volume XI: March 1990700 pp.; frontis., 4 pp. plates $\$ 98.00$

Prices are subiect to change and apply only in the U.S. To order, send check or money order to:

Humunities and Social Science's Marketing Department To order by phone using major credit cards, please call 
DEMOGRAPHY AND

DEGENERATION

Eugenics and the

Declining Birthrate in

Twentieth-Century Britoin

by Richard A. Soloway

\section{A CHANGING} OF THE GUARD

Anglo-American

Relations, 1941-1946

by Randall Bennett Woods
Richard Soloway offers an authoritative study of the relationship of the eugenics movement to the dramatic decline in the birthrate and family size in twentieth-

century Britain. "Sensitively and dispassionately displays the many unspoken assumptions that underlay eugenics."-R. K. Webb 464 pp., $\$ 45$

"A comprehensive account of the transfer of power from Britain to the United States and the first study grounded in now available official records and private papers on both sides of the Atlantic. ... An exhaustive and compelling analysis."-Theodore A. Wilson approx. 510 pp., $\$ 42.50$

available at

bookstores or from

THE UNIVERSITY OF NORTH CAROLINA PRESS

Post Office Box 2288

Chapel Hill, North Carolina 27515-2288

Toll-free orders: 1-800-848-6224 


\section{NEW FROM PRINCETON}

\section{Philanthropy and Police}

\section{London Charity in the Eighteenth Century Donna T. Andrew}

In this study of voluntary charities in eighteenth-century London, Donna Andrew reveals the interaction between charitable theorizing and practical efforts to improve the condition of the poor. The author argues that it is impossible to comprehend eighteenth-century charity without taking into account its perceived social utility. Cloth: \$32.50 ISBN 0-691-05557-2

New in paperback

\section{Sex and Suffrage in Britain, 1860-1914}

\section{Susan Kingsley Kent}

"[Kent's] starting point is that Christabel Pankhurst's cry, 'Votes for Women; Chastity for Men,' is less the manic aberration that historians have assumed than a statement of one motivating theme of the women's movement. Many women detected as a source and prop of their subordination, the sexual double standard. ... [Kent argues] originally and convincingly [that] 'private' and 'public' experiences were not distinct but closely interrelated; and many feminists perceived that the public world could not be reshaped without the private changing also."

-Pat Thane, Parliamentary History

Now in paper: \$12.95 ISBN 0-691-00852-3

New in paperback

Controversy in

\section{Victorian Geology}

\section{The Cambrian-Silurian Dispute}

\section{James A. Secord}

"This book aims at serious goals and achieves all of them. It provides a fundamentally new interpretation of the Cambrian-Silurian dispute based on exacting research and thoughtful interpretation. It also relates the dispute both to the general social background of British geology and to the distinctive personal experiences of Sedgwick and Murchison. Secord writes clear, vigorous prose and provides plenty of helpful illustrations. One cannot ask for more."

-William Montgomery, Science

Now in paper: \$16.95 ISBN 0-691-02441-3

AT YOUR BOOKSTORE OR

\section{Princeton University Press}

41 WIШAM ST. - PRINCETON, NJ 08540 • (609) 258-4900

ORDERS 800-PRS-ISBN (777-4726) 


\section{Historians on Historians}

"Although each book fits its subject into a place in the story of English historiography, the real interest in all lof them] tums out to be biographical. Not only the character and talents but the personal vicissitudes of the historian ... are fascinating."

- The Sunday Times (London)

\section{N A M I E R \\ Linda Colley}

"Countering the modern verdict of 'clever but overrated,' [Colley] feels that Namier's explication of the decay of the old European order is 'one of the best introductions to this century's insecurity, alienation, and angst.' ... one of the best introductions to Namier."

- Booklist

1989 ISBN 0-312-02854-7 \$24.95

\section{A C A U L A Y \\ Owen Dudley Edwards}

Macaulay's historical works have delighted readers and irritated academics ever since they were written. Edwards argues for Macaulay's serious purpose in writing - the drive to address the widest possible audience, and to draw his readers into sharing his own passionate love of learning and history.

1989 ISBN 0-312-02727-3 \$24.95

\section{H U M E \\ Nicholas Phillipson}

Phillipson's portrait of Hume is that of an intellectual who believed profoundly in the civilizing powers of culture, and who spent his actual career trying to manipulate the culture of his contemporaries by teaching them to think historically about themselves and their country's people. 1989 ISBN 0-312-03076-2 \$24.95

\section{G I B B O N Making History} Roy Porter

Porter's incisive portrait examines the special - and controversial - qualities of Gibbon as historian, showing the man, the mind and the history as inevitably, complexly intertwined.

1989 ISBN 0-312-02728-1 \$24.95

\section{A C T O N}

\section{Hugh Tulloch}

"Power tends to corrupt and absolute power corrupts absolutely." Such is the sole popular legacy of Lord Acton. Tulloch redeems Acton to history, depicting him as a thinker who addressed himself obsessively to matters of vital and lasting historical importance.

\section{St. Martin's Press}

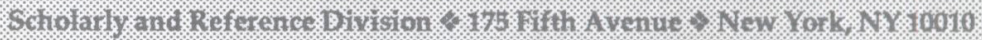

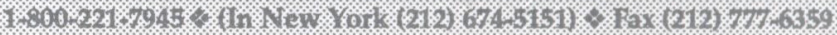

